\title{
KNOWLEDGE MANAGEMENT IN TAX ADMINISTRATION: A CASE STUDY IN INDONESIA
}

\author{
Gatot Subroto \\ Directorate General of Taxes, Jakarta. Email: gatot.subroto.19@ucl.ac.uk
}

\section{ABSTRACT}

Knowledge Management (KM) development in the public sector is relatively lagging behind compared to that in the business. Tax administration is no exception. This is contrary to the fact regarding the abundance of knowledge in the process of taxation, as well as the magnitude of the potential benefits KM may bring in advancing tax administration. The literature review in this paper identifies various types of knowledge in tax administration and classifies at least three major benefits of KM in the taxation process, which are related to the improvement of tax administration, tax compliance, and the prevention of maladministration and misappropriation in the tax administration and around the taxation process. Unfortunately, KM for tax administration is less attractive for both practitioners and academics. Trying to fill the gap, this research investigates the KM implementation in the Indonesian tax administration, Directorate General of Taxes (DGT). Data is collected through interviews, document analysis, and observations. This research finds that the KM initiative is still relatively in its infancy in terms of awareness and readiness. In the midst of low support from the top management and despite various developed and deployed IT system, the KM program tends to implement personalization strategy. The research also measures the maturity level using General KM Maturity Model (G-KMMM) developed by Pee \& Kankanhalli (2009) and finds that the overall level of maturity is still at level 2 (aware). A generic KM Model for tax administration is proposed. This model combines various types of knowledge in each cluster of tax administration business process, which is then consulted with the components that form knowledge definition by Davenport \& Prusak (1998) and the shapes of knowledge by Nonaka \& Takeuchi (1995). The model provides insights regarding system development strategy and reveals some obstacles to be overcome. In addition to accommodating explicit knowledge in codification strategy, technology should also be developed to support personalization.

Keywords: knowledge management, tax administration, KM in public sector, KM Model for tax administration, KM maturity level. 


\section{ABSTRAK}

Perkembangan Manajemen Pengetahuan (KM) di sektor publik relatif tertinggal dibandingkan dengan yang ada di bisnis. Tidak terkecuali di administrasi pajak. Ini bertentangan dengan fakta mengenai keberlimpahan pengetahuan dalam proses perpajakan serta besarnya manfaat potensial yang dapat dibawa oleh KM dalam memajukan sektor perpajakan. Tinjauan pustaka dalam makalah ini mengidentifikasi berbagai jenis pengetahuan dalam administrasi perpajakan dan mengklasifikasikan setidaknya tiga manfaat utama KM dalam proses perpajakan, yang terkait dengan peningkatan kinerja administrasi perpajakan, peningkatan kepatuhan pajak, dan pencegahan maladministrasi dan penyalahgunaan dalam administrasi perpajakan dan sekitar proses perpajakan. Sayangnya, KM untuk administrasi pajak belum menarik perhatian praktisi dan akademisi dalam bidang tersebut. Mencoba mengisi kekosongan itu, penelitian ini menyelidiki implementasi KM dalam administrasi pajak Indonesia, Direktorat Jenderal Pajak (DJP). Data dikumpulkan melalui wawancara, analisis dokumen, dan observasi. Hasil penelitian menunjukkan bahwa inisiatif KM masih relatif baru dalam hal kesadaran dan kesiapan. Di tengah rendahnya dukungan dari manajemen puncak dan sekalipun berbagai sistem teknologi informasi (IT) telah dikembangkan dan digunakan, program KM cenderung ke arah strategi personalisasi. Penelitian ini juga mengukur tingkat kematangan dengan menggunakan General KM Maturity Model (G-KMMM) yang dikembangkan oleh Pee \& Kankanhalli (2009) dan menemukan bahwa tingkat kematangan secara keseluruhan masih di level 2 (sadar). Pada bagian akhir, Model KM generik untuk administrasi pajak diusulkan. Model ini berasal dari kombinasi jenis-jenis pengetahuan dalam setiap kelompok proses bisnis administrasi perpajakan, yang kemudian dikonsultasikan dengan komponen-komponen yang membentuk definisi pengetahuan oleh Davenport \& Prusak (1998) dan bentuk-bentuk pengetahuan oleh Nonaka \& Takeuchi (1995). Model ini memberikan sejumlah wawasan mengenai strategi pengembangan sistem KM, bersama dengan beberapa kendala yang harus diatasi. Singkatnya, selain mengakomodasi pengetahuan eksplisit dalam strategi kodifikasi, teknologi juga harus dikembangkan untuk mendukung personalisasi.

Kata Kunci: manajemen pengetahuan, administrasi pajak, KM di sektor publik, Model KM untuk administrasi pajak, Tingkat kematangan KM.

\section{A. BACKGROUND}

After a long time becoming the attention in business sector, knowledge management (KM) has grown as a new discipline. As in many countries, public sector institutions in Indonesia also rarely apply $\mathrm{KM}$. While the literature has addressed issues, challenges, and opportunities of $\mathrm{KM}$ for the private sector, little has been discussed for the public sector. The study conducted by 
Cong et al. (2007) suggests that Cong et al. (2007) suggests that KM in the public sector is still in its infancy and has a long way to go in the KM journey.

In tax administration, KM discourse is even rarer. Not much academic work discusses the implementation of $\mathrm{KM}$ in tax administration. Although taxation is the most researched topic in the fields of economy, administration, politics, or even information systems, it has seldom been approached from a knowledge - based perspective. This is an irony because it is recognized that tax administration is a sea of knowledge (Sejdija 2012; Haseldine et al. 2011; Evans \& Carlon 2015).

\section{A.1. Research Problems}

Nevertheless, the tax administration of Indonesia, the Directorate General of Taxes (DGT), has already initiated several KM initiatives. Amid the rapid changes in the era of knowledge-intensive economy, DGT has initiated the KM program since 2008. This paper analyzes the knowledge management system of the Indonesian tax administration from three dimensions, namely process, people, and technology.

Some problems are intriguing and interesting to investigate further. The first is whether KM in DGT has worked well. To answer that question, it is necessary to learn how KM practices have been going on in the tax administration, as well as to identify the problems and then how to solve them. Also, when KM is believed to improve organizational performance, it is interesting to identify the areas where KM can contribute much to improve the performance of tax administration and how to realize it. Finally, this article is hoped to come up with a proposal of KM Model for typical tax administrations.

\section{A.2. Research Benefits and Contribution}

This research is expected to bring benefits at theoretical and practical levels. First, it contributes to the development of the body of knowledge in KM. This research does specifically focus on the case of $\mathrm{KM}$ in tax administration, but it has a wide interpretation. The study reveals the practice of KM in the taxation sector can strengthen understanding in the field, especially in the context of developing countries. As mentioned, there is a KM literature gap for tax administration. To bridge this gap, the paper examines how KM practices work to influence the tax administration process and performance. At least, as it is targeting the very specific issue of $\mathrm{KM}$ in tax administration, this study could be the basis for further studies.

Secondly, at a more practical level, this research might help tax administrations be improved in managing their knowledge and performance. KM can be a powerful tool to improve organizational performance. In a nutshell, this research carries a noble mission of building a KM model suitable for a typical tax administration that can be applied to any tax administration. 


\section{B. LITERATURE REVIEW}

Many sources and materials are available to describe $\mathrm{KM}$ with diverse scopes and contexts from a variety of disciplinary perspectives. By reviewing these, it is hoped that the theoretical basis will be obtained as a basis to develop research questions and propositions as the starting point of this research. In addition, there will be a review of the tax administration literature and the approaches to analyze KM in the public sector in order to find the most appropriate way to achieve the research objectives.

\section{B.1. KM in Theory}

KM was first conceptualized in the 1990s, where it was facilitated by the globalization of economies and markets, knowledge-intensive products and services and the rapid development of information technology (Alavi \& Denford 2001). The study of KM was developed by Drucker (1993) in terms of knowledge-intensive firms and the fundamental role of their knowledge workers.

Most KM definitions are based on processes. Alavi and Leidner (2001) propose one of the most widely cited frameworks comprising four processes: creation, storage retrieval, transference and knowledge application. Other scholars have mixed opinions; Nonaka \& Takeuchi (1995) call the processes in KM definitions as the creation, access, dissemination, and application of knowledge; Lin (2014) mentions the generation, access, facilitation, integration, embedding, application, transfer, and protection of knowledge. Similar to these views, Kianto et al. (2016) suggest that KM processes can be divided into five main types: knowledge acquisition, knowledge sharing, knowledge creation, knowledge codification, and knowledge retention.

Regarding strategy, Hansen et al. (1999) classify knowledge management into two types: codification strategy and personalization strategy. The knowledge that is carefully codified and stored in databases, where it can be accessed and used easily by anyone in the company is called codification knowledge management strategy. This approach allows many people to search for and retrieve codified knowledge without having to contact the person who developed it. On the other hand, personalization knowledge management strategy happens where knowledge is closely tied to the person who develops it and is shared mainly through person-to-person contact. It provides creative, analytical rigorous advice, and high-level problem solving by channeling individual expertise.

$\mathrm{KM}$ is done with various intents and purposes, among others, to avoid reinventing the wheel, to anticipate knowledge walk-out, and to support innovation (Dalkir, 2011). KM is believed to bring a number of benefits to organizational performance through a number of variables, such as innovation, job satisfaction, productivity, and capacity building, all of which lead to better processes and 
better products/services (Soo, Devinney, Midgley, \& Deering, 2002).

\section{B.2. KM in Public Sector}

Scholars who examine $\mathrm{KM}$ in the public sector are rare. When a journal discusses the development of KM, then it is most likely focused on the business sector. Serenko (2013), for example, illustrates the historical development of KM from 1990 but entirely refers to the private sector. Even Castaneda et al. (2018) who surveyed thousands of journals did not mention KM in the public sector at all.

Knowledge management as a new managerial practice and as an academic research topic remains limited in the public sector literature. This is surprising as public sector organizations can be classified as knowledge-intensive organizations. All organizations are to some extent knowledge intensive. However, some organizations have knowledge as their core product, provide knowledge to the public as their main activity, or have mainly knowledge workers. This is the characteristic of most public sector organizations (Willem \& Buelens 2007).

Broadly speaking, the challenges in private and public sectors are equally facing the challenges of finding a suitable KM form, that is how to generate and capitalize the knowledge. The relationship between the two sectors has become a long scholarly discussion. Some think that the differences between the two sectors are converging; others think the differences are so large that business practices cannot be transferred directly to the public sector (Boyne, 2002). Although management that is common to all organizations can be applied to public sector organizations, yet entirely copying management practices from the private sector without considering public sector features and contexts is likely to fail. Each of the two sectors has a particular emphasis, therefore different approaches should apply (Cong, Li-Hua, \& Stonehouse, 2007).

However, many believe that the public sector faces even greater challenges. In terms of establishing a learning culture, for instance, the public sector must first overcome structural and cultural obstacles. Consequently, it is proposed that there is a need for a strategy designed especially for the public sector to be developed to fill the gaps and for cross-learning.

The public sector, especially the government sector, delivers intangible services and goods/products, which mainly are public service and policy. Therefore, public sector organizations are primarily knowledge-intensive organizations, and to exploit their knowledge, effective knowledge sharing among the different departments is required (Willem \& Buelens 2007). It can be said that the effective functioning government rests on effective acquisition and dissemination of knowledge.

Why is KM in the public sector relatively less advanced? One explanation is perhaps the lack of competition as an important driving force (Sejdija, 2012). 
Furthermore, pressures (budget, politicians, public) force public officials to be more cautious and, therefore, slower in acting. In addition, in the private sector where the procurement system is relatively easy and agile, KM development is also driven by the role of consultants and other market actors related to $\mathrm{KM}$. On the other hand, it is not easy for the public sector to get that kind of freedom.

\section{B.2.1. Knowledge in Tax Administration}

Among government sector organizations, tax administration is supposed to be the most knowledgeable and therefore more urgent to do KM. First, the sectoral uniqueness of tax administration that is close to the taxpayer, namely the business. Although Boyne (2002) states public and private differ in many aspects, the tax administration position is closer to the private side. In order to carry out the task of collecting taxes effectively, tax administration must understand the behavior of the taxpayers, along with the knowledge they have.

Second, most of the tax administration works involve humans. Although technology has grown rapidly, the human central roles have not declined in the process of raising tax money. Indeed, the knowledge resides in the heads of the humans. The knowledge - based perspective puts great emphasis on human capital. As human intelligence is tacit, embedded, and at least partly individual, it can not be simply "captured and codified", which makes its management problematic (Kianto et al. 2016).

Third, the nature of the tax administration business itself is extensive. Like other public organizations, the main task of tax administration is policy-making and service delivery. There are indeed differences in job coverage and institutional arrangement of tax administrations among countries. This is influenced by institutional history, economic structure, legal tradition, the type of taxes administered, and so on. In general, however, the tax administrations have some business processes that are typical for any tax administration, such as taxpayer registration, return processing and payment, supervision and audit, dispute resolution, collection, and criminal investigation (Alink \& van Kommer 2011). A tax administration also performs support functions such as tax education, public relations, data analytics, and internal resource management.

This makes the tax administration almost totally a knowledge-based organization. Knowledge is, therefore, the most important potential factor, namely as the production factor itself. The tax administration possesses knowledge about the society, the lawful or unlawful behavior of taxpayers; knowledge about the administrative actions and their effects; about laws, regulations, and directives and finally about themselves as an organization. All this has clear and unclear components and is dispersed in files, documents, databases and especially human heads (Sejdija 2012). 
In the context of policy making, tax administration helps the government design, formulate, implement, and evaluate tax policies. This again makes the tax administration, as a whole, a knowledge-based environment where tax officers are facing great challenges due to the permanent flood of new information such as frequent changes in legislation, new court decisions, and directives (Sejdija (2012) refers to Yuen (2007)). In essence, the scope of the tax administration works is so broad and rapidly changing that it has to be agile and work systematically.

Fourth, when knowledge is recognized as an intangible asset for most organizations, in the world of taxation, knowledge is relatively more tangible. The knowledge is a product that can be traded. It is called tax knowledge, which is the process by which taxpayers become aware of tax legislation and other tax-related information (Haseldine et al. 2011). In contrast to knowledge in other organizations, tax knowledge closely matches the accounting definition of intangible assets. Furthermore, there is also a market for tax knowledge. As Haseldine et al. (2011) suggest, basic participants in the tax system are regarded as market players, comprises sellers, buyers, and brokers. A tax authority is the producer and seller of this knowledge. Taxpayers, basically companies, are buyers of tax knowledge. Consulting companies providing services in the field of accounting and taxation are brokers that intermediate the transactions (Evans \& Carlon 2015). This differs from market knowledge elsewhere according to Davenport \& Prusak (1998), which takes place internally between employees with pricing and payments in the form of reciprocity, reputation, and altruism.

Fifth, because tax knowledge is marketable and abundant, then it is vulnerable to be exploited and abused. Knowledge is power, and therefore, according to Soo et al. (2002), unless carefully managed, knowledge may become a dark power. One of the many differences between the public and private sectors, typically found in tax administration, is the risk of corruption. This factor overshadows any decision-making, financial transactions, or even every activity, especially in developing countries. In general, there are prevalent risks of misuse of knowledge in the public sector, let alone those associated with taxation because of its strategic and lucrative nature of work.

\section{B.2.2. Typology of Knowledge in Tax Administration}

As recognized by Davenport \& Prusak (1998), knowledge is complex. Knowledge may be viewed from diverse perspectives: as a state of mind, as an object, as a process, as a condition of possessing access to information, or as a capability (Alavi \& Leidner 2001). The other most common way to define knowledge is to distinguish it from information. A number of scholars present the definition of knowledge with an emphasis on the dimensions and components of knowledge. According 
to Davenport and Pruzak (1998), knowledge can be classified as professional insight, experience, values, and context information.

In public administration, Lenk and Wengelowski (2002), quoted by Sejdija (2012), detect three types of knowledge groups, namely (i) knowledge about processes and procedures;

knowledge about cases and contents (contains facts and rules), and (iii) contextual knowledge ("world knowledge"). This grouping can also be applied in tax administration. A typical process within the tax administration is characterized by the determination of what is to be taxed and to which amount. These actions are well-structured but there are also unstructured production processes. In the end, the case officer must be aware of the processes and procedures to (inter)act in the most optimal way (Sejdija, 2012). Knowledge of cases is meant by knowledge about current and closed cases. Many open-ended processes such as the controversial taxation of tax bases or negotiated tax bases produce their own story.

The knowledge of content can be broken down into the knowledge of facts and rules. An important subordinate of knowledge of rules is the legal knowledge. This type of knowledge is provided by different (semi-) professional sources (e.g., codes of law, juridical information systems). Contextual knowledge describes knowledge about the environment and the world as a whole. It serves the understanding of facts of a case and is not clearly separable from knowledge about cases (Sejdija, 2012).

\section{B.2.3. The Idiosyncrasy of $\mathrm{KM}$ in Tax Administration}

Tax system, administration, and tax compliance at all levels are knowledge demanding activities. Taxation, which is very important for government, sub-central fiscal authorities, businesses and all citizens, is a complex reality in the search of a supporting knowledge management theory (Sestakova 2017). However, KM is less developed in tax administration or even unpopular. Knowledge management issues and knowledge transfers in tax administration (especially tacit knowledge sharing) are scarcely analyzed in the literature and are not sufficiently supported by official tax policies. Then why, despite a lot of knowledge wandering in tax administration, KM is less developed in the area. In general, government institutions have organizational characteristics that are less beneficial for knowledge sharing (Willem \& Buelens, 2007), but the tax administration has other additional reasons.

First, the nature of knowledge is intangible. Knowledge is believed to bring benefits to better processes and better products/services (Soo et al., 2002). KM is not popular in the tax administration perhaps, inter alia, because of the knowledge forms (and the benefits of KM itself) are mostly intangible, unlike the "product" of tax administration, such as revenue which is relatively easy to measure with an amount of money.

Second, lack of sense of competitiveness. Feeling not in 
sees no threat and therefore there is no urgent need for survival and innovation. Different conditions within the business sector, the taxpayers, who always try to outperform each other in a competitive economy through cost efficiency and better products. However, it is not true that tax administration is not in a competitive environment. In the era of globalization, the tax regime becomes an important determinant of business and investment that affects the competition between countries, which is often a factor of a country to compete at the global level. Even if not competitive, domestically the tax administration is at a heavy press in the relations between the people and the state.

\section{RESEARCH METHODOLOGY}

This research attempts to expose the central phenomenon of $\mathrm{KM}$ that occurs in DGT. The first part will draw on KM's background and history in the organization, from which a lesson is expected to be learned for future KM projections. This is important because according to Edwards et al. (2005), the history and background of $\mathrm{KM}$ in an organization form an important part of the relevant context and contribute to future knowledge management activities. There are three main objectives of the study placed within the research framework, namely (i) photographing the KM initiatives that have taken place in the $D G T$, (ii) measuring the maturity level of the KM, and (iii) building a KM model for tax administration. Simply put, all the three objectives can be described in the following research framework.
Third, the pattern of rivalry relationship among the parties. This argument comes from a perspective that sees the market for tax knowledge and the rarity of knowledge sharing around taxation. The basic reason behind this situation is that the interrelations between the main players in the field (tax authorities, taxpayers, and national governments.) are based more on rivalry than on cooperation (Sestakova, 2017). It is believed that the benefits of some players can be just the detriment of others. Unfortunately, Sestakova (2017) defines KM as just an external transfer of knowledge among organizations and does not see any possible partnership relationship among tax actors.

\section{C.1. Portrait KM in DGT}

Portraying KM initiatives at DGT draws some questions concerning the starting point of the KM initiative, how the awareness of and readiness for KM and what strategies are implemented, following with the barriers of implementation. To answer these questions, propositions are needed to be constructed.

The concept of $\mathrm{KM}$ is nothing new (Hansen et al. 1999). Organizations have always used KM practices to make decisions and to produce goods and services, though not in a deliberate and systematic manner. Essentially, what's new is the consciousness or awareness of the systematic concept of KM.

Proposition 1: awareness and readiness of KM in DGT have not been high. 
A successful KM initiative, in addition to leadership support and ownership, also requires the appropriate strategy. Hansen et al. (1999) divide the KM strategy as codification vs. personalization. Therefore, KM initiatives in an organization should choose either a system-oriented strategy or a human-oriented strategy. At DGT, because the IT system for KM is not very good yet, then the KM strategy is likely to be personalized.

Proposition 2: KM strategy in DGT is emphasizing personalization.

How does DGT develop KM when the concept of KM itself has not been popular for public administration, let alone for tax administration? DGT begins to apply $\mathrm{KM}$ by learning from the business sector and relying on advice from consultants and comparative studies. Learning directly from business practitioners and trying to adopt the practice of KM based on advice given must always encounter obstacles or constraints.

Proposition 3: DGT faces constraints (barriers) in KM implementation.

\section{C.2. The Maturity of KM in DGT}

In general, KM elements include people, processes, and technology. People refer to people and organizations, the actors, including organizational culture and the relevant strategies and policies. For the process, there are various stages of the KM process that are delivered by many experts. In this study, the KM process is simplified in three subprocesses, namely acquisition, distribution, and utilization (abbreviated as ADU). A includes the processes of knowledge creation and acquisition, which involves the generation of new knowledge within an organization and the acquisition of knowledge from external sources. There are still a variety of other terms that are often used interchangeably, such as acquiring, generating, creating, modifying, combining, gathering, and recombining. While D (distribution) consists of sharing, transferring, and disseminating knowledge, U (utilization) consists of using, incorporating, applying, or harnessing. The last element is technology, which theoretically refers to the availability of information system to support KM.

It is assumed that KM in DGT is still in the development phase. All KM elements may still be in progress. The maturity level will be measured by using the General KM Maturity Model (G-KMMM) developed by Pee \& Kankanhalli (2009). Containing five levels of maturity: initial, aware, defined, managed, and optimizing for every people, process, and technology, the framework provides assessment instruments measuring each level. Another reason for using G-KMMM is because the scheme is quite general and more or less the same as other measuring tools, such as the KM life cycle by Edwards et al. (2005) which divides KM development into four stages. However, taking into account several limitations of the model, the diagnosis using G-KMMM is done with slight modifications on how to use the level number. 


\section{C.3. The Development of KM Model for Tax Administration}

The third purpose of this study is to develop a KM model that is appropriate for tax administration. Firstly, it tries to explore the potential of knowledge circulating in tax administration. The knowledge is categorized into four types; procedure, content, case, and context (Lenk \& Wengelowski 2002; Sejdija 2012). Secondly, based on the grouping, the research will explain how the tax administration may conduct KM optimally. Here, each type of knowledge is tested with components that construct the definition of knowledge proposed by Davenport \& Prusak (1998). Thirdly, by exploring the potential of KM in the tax administration body, according to typical tax administration business process, it is expected that a KM model suitable for tax administration can be constructed.

In the end, there will be a discussion to explain in what field or process that KM can contribute to improve tax administration. Therefore, the operational objectives of this study are also to describe KM practices in DGT for each process and each type of knowledge.

\section{C.4. Data Collection and Analysis Methods}

To achieve the research objectives, there are two major frameworks of research methodology. The first stage is positioned as an exploratory study by collecting first- hand information on how KM is perceived and implemented in the DGT. The second stage is a formative research in order to develop an ideal KM model for tax administration.

A flexible method is essential to tap the context of how DGT is striving to manage knowledge. This study adopts a qualitative methodology which entails an in-depth case study of DGT's KM. This methodology explores the phenomenon under investigation, which is considered appropriate in order to examine a phenomenon in a real-life context (Yin, 2014). Data are gathered by collecting multiple sources of evidence through documentary analysis, semi-structured interview, and participating observations.

The first data collection approach is documentary analysis, by collecting various documents from both within and outside the organization - both published and unpublished. Internal documents include memos, circular letters, strategic plans and meeting minutes, as well as presentation materials and intranet sites. In addition, public documentation such as government's website, annual reports, corporate profile, and online web-based news are also gathered from the internet or other sources.

Further, data and information are collected through discovery-oriented interviews. The participants in the semi-structured interview have sufficient experiences and understanding of the situation within the KM process. Employees and managers at various functions nationwide are asked for their opinions on KM which exists in 
every process or activity of the tax administration. This is conducted because the KM initiative has begun to be implemented and put into practice in various areas. Some participants have involved in the KM policy-making and implementation.

\section{FINDINGS AND OUTLOOK}

After data collection and analysis are conducted, several interesting findings are drawn. It is true that the KM initiative in DGT has started to run and is now increasing, even though the maturity level is very low and still needs improvement. Nevertheless, the KM's initiative finds patterns and contents that offer valuable lessons and can serve as a basis for developing a KM model for tax administration.

\section{D.1. Description of KM in DGT}

DGT is one of the largest organizations in Indonesia in terms of the number of employees (about 42,000) and the work units (over 500). Responsible for collecting around 75\% of total state revenues (Rp1.894 trillion in 2018), DGT deploys its organizational structure throughout the archipelagic country. As with most tax administrations, DGT also performs various functions, from taxpayer registration to tax crime investigations, as well as corporate functions like most institutions do.

Taking into account the size of the organization and the complexity of tasks and functions, it can be ensured
To achieve the last research objective; to explore the potential of knowledge and construct a KM Model, the data collection methods are combined with participating observation. This approach is appropriate for studying KM- in-progress, as well as KM's usefulness and development.

that in every process there is much explicit and tacit knowledge moves around. As an institution with holistic authority, from service to law enforcement, DGT has a wide range of knowledge (specialization, profession, disciplines, skills). In serving the public (taxpayers), DGT plays various roles and functions to deal with customers, human capital, and stakeholders. Not surprisingly, with varying intensity and concentration, all types of knowledge can be found in the tax administration processes and divisions.

However, as can be predicted, the abundance of knowledge is not managed well. This is actually an international phenomenon; there have not ben a lot of tax administrations that organize KM well.OECD, that periodically conducts surveys and comparative reports on tax administration transformations worldwide, never covers issues on KM and their roles in advancing taxation. In fact, some countries have recently had a dedicated KM function in their tax administrations, such as the Australian Tax Office and the Kenya Revenue Authority, showing that there have been serious efforts and attention to 
practice KM. However, OECD has published publications of KM, although only limited to the field of auditing (OECD, 2006).

Indonesian tax administration itself has tried to start the KM initiative since 2008, long before the management of knowledge has been practiced traditionally. Some examples of common KM practices include training and education, in-house training, technical guidance, and workshops. But it was just recently that the DGT exercised it with a more systematic approach according to the contemporary KM discipline.

\section{D.1.1. Awareness and Readiness of DGT for KM}

In light of the stepstone of its development, although in 2008 there has been a discourse of KM, only later in 2011 there was a real action in the form of KM design proposal. Assisted by a business consultant and IT system providers, DGT developed KM blueprints. Other helpful parties were donors that have been actively encouraging tax reforms such as the World Bank, JICA, and GIZ. However, the blueprint only stays in the filing cabinet and does not seem to manifest in reality.

After approximately five years of almost vacuum, in 2016, KM development was finally declared formally in the regulation as one of the areas of business process development. Implicitly, the KM movement has also been sounded in the strategic plan through efforts to improve the competence and quality of work. KM is also put on the agenda of tax reform and the development of the IT core tax system.

In 2017 as a manifestation of the task of business process transformation, Kompatriot was initiated as a new brand for KM campaign. Kompatriot is defined as a knowledge management system of DGT which is integratively conducted by consolidating clustered sectoral knowledge and keeping the autonomy of expertise and sectoral KM owners. Transcribed from the English word of "compatriot" (\kəm-'pā-trē-ət, a fellow citizen or national of a country), Kompatriot is intended as a national KM flagship to unify the KM clusters that previously existed and operated separately.

Additionally, in 2017 Kompatriot participated in MAKE Study, becoming the only government agency as the participant. 1 This shows the KM program's readiness to move toward a more mature direction, including attracting the manager's perspectives and support. Given these facts, KM awareness has begun to take shape.

Even so, KM in reality has not contributed significantly, especially in creating a big impact on the performance of the organization. In strengthening the organizational commitment, for example, the KM has not been able to overcome the knowledge walk-out due to staffs leaving the organization either by retirement or resignation. Most of the retired employees are the baby boomers who have robust tacit knowledge and 
wisdom from long experience in duty. On the other hand, employees who resign are a brain drain that contributes to double-loss of DGT. They, still in productive age, went out with congregated knowledge gained from a series of state-funded training and enriched by the accumulation of valuable and exclusive experiences within the organization. The irony is that the taken away knowledge is occasionally used in the market by tax consultants and large corporations to "fight back" the DGT. Viewing from the tax knowledge market theory by Hasseldine et al. (2011), this is one form of "free transfer" tax knowledge from a seller to a buyer and a broker. One special difference with this phenomenon is that it is not just the content that switches but also its entire packaging (container).

\section{D.1.2. The Strategy that Emphasizing Personalization}

Of the two common strategies of $\mathrm{KM}$; codification vs personalization (Hansen et al., 1999); DGT seems to move closer to the personalization. As mentioned, various kinds of conventional knowledge sharing that has been practiced so far are typically human-to-human approach. It is already institutionalized and still a common pattern of knowledge sharing. Although lately there has been a long-distance learning system through the internet, human-oriented strategies remain more dominant in DGT and also in most of the public sector in Indonesia.
System-oriented strategy and personalization, however, are not a mutually exclusive dichotomy, but merely indicate which one is more dominant. In a particular business process, codification can be more appropriate because most of the knowledge is explicit, while in other processes, personalization is more dominant. The practices of KM at DGT show that personalization is relatively better in areas where most of the knowledge is tacit, or still in the heads of individuals. Moreover, what distinguishes knowledge and information basically relies on the elements of the conversion by human intervention or human experience (Davenport and Prusak 1998).

Until the end of 2017, DGT has developed many IT systems for codification and repository, which consists of no fewer than 21 applications, portals, and databases. ${ }^{2}$ Among them, there is an example where codification succeeds, measured by the number of users and access frequency, that is at the e-Learning portal. In 2017, almost all DGT employees were suddenly excited about accessing the learning materials stored in the app. Several modules provided, especially with regard to taxation as well as personnel, finance, and general affairs. One probable explanation is the existence of the key performance indicators that ask every employee to learn through e-Learning. If an employee did not access the materials at the required amount and duration, then his/her performance will be rated poor and this affects the grade 
of allowance and take-home pay. A lesson learned from this case is that there must be coercion (mandatory participation) and the threat of adverse consequences to encourage employees to involved in KM.

On the other hand, there is a weakness that is quite fundamental, i.e. the fact that DGT has never done a knowledge audit. Many scholars and KM practitioners believe that a knowledge audit is one of the prerequisites for KM to run smoothly. As a consequence, the gap between knowledge holders and seekers is still unknown in DGT. The implementation of KM still seems haphazard to cause knowledge scattered. This, of course, contrasts with the fact of the abundance of knowledge in the tax administration and around the taxation environment as a whole.

\section{D.1.3. Barriers in Implementing KM}

Obstacles in KM implementation are inevitable, as is the case in DGT. However, constraints are rarely revealed in documents. Thus, to reveal them, it was necessary to interview a number of parties, in particular the managers and staffs responsible for developing KM at the central level. The main findings of the interviews can be summarized as follows.

First, leadership support. There was little evidence of anyone at senior management level having previously taken ownership of knowledge management. Some interviewees believe that leaders who do not provide explicit support can turn into obstacles.
The top-level managers, some others argue, are still too focused on the pursuit of the target revenue, as its rewards are more real and direct. The management does not see KM's direct links to performance, or the contribution of KM to the achievement of the already set targets.

Second, organizational silos impede knowledge sharing internally. Whatever the cause, fragmentation tends to make people behave partially and independently. It is getting worse with the implementation of the performance management system, in which each party is busy with the achievement of its own key performance indicator (KPI), or even involved in an inter-division battle or career-pursuing competition at the individual level.

Third, the IT systems are not integrative. Some directorates create their own information systems, but the patterns just follow the hierarchy of organizational structures, thus reinforcing the silos. Developed in-house, the IT systems also tend to be partial to just accommodate the interests of the owner. One KM champion urges that DGT actually already has a SharePoint-based internal portal, that should be able to play the integrating role, but unfortunately the system is out of date.

Fourth, low knowledge sharing culture, even some divisions tend to practice hoarding knowledge. Examples for this case relate to those who have the special and unique knowledge, such as advanced transaction tax issues. For different reasons, intelligence-related 
divisions also tend to prioritize the secrecy aspects rather than sharing knowledge. But the propensity of hoarding knowledge is also caused by the shape of the knowledge itself that is very particular (not general). This confirms what Gronau et al., (2016) presume that particular knowledge is not very useful for others. It should be realized that $\mathrm{KM}$ is still perceived as a new thing and has not been widely understood, so it must be admitted that the collaborative culture subsystem has not yet been well established. Although the traditional practices of knowledge transferring have been practiced for a long time, most employees still do not see the clear and reliable benefits of KM.

Still related to the obstacles in knowledge distribution, DGT also faces the low interest in reading. This relates to Indonesian reading culture as a whole. Of course, this is a serious barrier, because no matter how sophisticated KM system is designed and how much knowledge is codified, but if the interest of the users to access and read is low, then it will all be useless.

\section{D.2. Maturity Level of KM in DGT (PRESENT)}

This section discusses the maturity level of KM in DGT in light of the elements of $\mathrm{KM}$ which include people, processes, and technology. The study explores these overall elements from various sources of data and information (primarily from interviews) which are then measured by using G-KMMM proposed by Pee \& Kankanhalli (2009).

\section{D.2.1. People}

The "people" refers to the actors, both humans and organizations. In the context of KM, the human element also refers to two contexts, namely the human resources allocated for $\mathrm{KM}$ and the readiness of human culture to be open to KM.

In the first context, the elements of people should be reflected in the organizational dimension according to the major theoretical framework provided by Nonaka and Takeuchi (1995). Based on the information gathered in interview sessions and source documents, there are several formal divisions in DGT working on KM, i.e. the directorate of service, education, and public relation (whose work is related to tax knowledge base (TKB), library and internal portal management); directorate of internal compliance and human resource transformation (having the task of the improvement of employees' capacity), and the directorate of business process transformation (in charge for the development of KM for DGT). For information technology (IT) matters, there is a central service of information system (Lasis) in the IT directorate, where operators could seek solutions to any problem encountered in the field (thus the Lasis is closer to the troubleshooter function). However, in theory, formal organizations are often different from existing organizations, the real one that may be different from the formal statutory organizations (Schlemenson 1992). From the existing organization perspective, 
several divisions, as a matter of fact, perform the activities or development of KM although their official tasks do not cover the function of KM explicitly. For example, the directorate of audit and collection which administers the KM in the field of auditing and the directorate of revenue and compliance that manages the knowledge concerning "the excavation" of potential taxes (penggalian potensi pajak) for compliance supervision purpose.

According to formal organizational tasks, headquarters and regional offices hold the function of providing guidance (bimbingan), a kind of a top-down knowledge sharing. These activities are commonly held especially during the enactment of new policies, regulations, information systems and business processes. Although the shared knowledge is more theoretical in nature, in many cases, the guidance-provision activities may combine the theoretical knowledge with the empirical one which is captured from the field (work units), which usually, as Davenport \& Prusak (1998) state, has ground truth.

Table 1 Maturity Level of KM in DGT: People

Source: Pee \& Kankanhalli (2009) and Researcher's Analysis

\begin{tabular}{|c|c|c|}
\hline Level & G-KMMM's Assessment Instruments for People & Main Reponses \\
\hline \begin{tabular}{c|}
1 \\
Initial \\
\end{tabular} & No KM initiatives & \\
\hline \begin{tabular}{|c|}
2 \\
Aware
\end{tabular} & $\begin{array}{l}1 \text { Is organizational knowled ge recognized as essential for the long-term success of the organization? } \\
2 \text { Is KM recognized as a key organizational compe tence? } \\
3 \text { Employees are ready and willing to give advice or help on re quest from anyone else within the } \\
\text { company }\end{array}$ & $\begin{array}{l}\text { Yes. } \\
\text { Yes. } \\
\text { Yes, but on request. }\end{array}$ \\
\hline $\begin{array}{c}3 \\
\text { Define }\end{array}$ & $\begin{array}{l}4 \text { Is the re any incentive syste m in place to encourage the knowl edge sharing among employees? } \\
\text { - Empl oyee's KM contribution are taken into consideration } \\
\text { - Rewards for team work, knowled ge sharing/re-use } \\
5 \text { Are the incentive syste ms attractive enough to promote the use of KM in the organization? } \\
6 \text { Are the KM projects coordinated by the management? } \\
7 \text { Are there individual KM roles that are de fine d and given appropriate degree of authority? } \\
\text { - CKO or - Knowle dge Officers / Workers } \\
8 \text { Is the re a formal KM strategy in place? } \\
9 \text { Is there a clear vision for KM? } \\
10 \text { Are there any KM training programs or awareness campaigns? e.g. introductory/specific workshops } \\
\text { for contributors, users, facilitators, champions }\end{array}$ & $\begin{array}{l}\text { Partly Yes } \\
\text { No. } \\
\text { Yes, just started. } \\
\text { Yes, but ad hoc. } \\
\text { No, in progress. } \\
\text { Yes, but informal. } \\
\text { Yes. }\end{array}$ \\
\hline $\begin{array}{c}4 \\
\text { Managed }\end{array}$ & $\begin{array}{l}11 \text { Are there regul ar knowled ge sharing sessions? } \\
12 \text { Is KM incorporate d into the overall organi zational strategy? } \\
13 \text { is the re a budget specially set aside for KM? } \\
14 \text { Is there any form of bench marking, measure, or assessment of the state of KM in the organi zation? } \\
\text { - Balanced scorecard approach; - Having key performance indicators in place; - Knowle dge ROI }\end{array}$ & $\begin{array}{l}\text { Yes, but less regular. } \\
\text { No. } \\
\text { No. } \\
\text { Yes, jus for e- } \\
\text { Learning } \\
\end{array}$ \\
\hline $\begin{array}{c}5 \\
\text { Optimising }\end{array}$ & 15 Has the KM initiatives resul ted in a knowled ge sharing cul ture? & No. \\
\hline
\end{tabular}

In connection with knowledge sharing culture, as mentioned previously, the culture has not been formed maturely. Instead, the low sharing culture still appears as an obstacle. Interview sessions discover several reasons behind this.
In addition to organizational silos and the fear that others being smarter (the owned knowledge is no longer exclusive), it is also because the sharing activity itself is not encouraged by the organization or at least poorly facilitated. 
When measured using the G-KMMM scheme, DGT appears to be at level 2 (aware). This is supported by the interviewees' claims that organizational knowledge has been recognized as an important factor for the long-term success of the organization. Furthermore, the employees are also better equipped to provide advice or helps to other employees, even though most of them are by request. The maturity has not reached level 3 (define) or higher because there are no incentive systems, dedicated units, nor formal KM strategies in place that is designed to achieve the vision of KM (of which has not been formally formulated yet). DGT also has not set individual KM roles, such as chief of knowledge officer (CKO) or knowledge officers who have clear authority in the operation of KM. At the time of the research, DGT already had a certified knowledge manager (CKM), but he did not work in a dedicated division, yet only ad hoc in the business process transformation division.

\section{D.2.2. Process}

While viewed from the process cycle, many findings deserve to be brought to light in three simpler subprocesses of acquisition, distribution, and utilization (ADU). Subprocess acquisition includes knowledge acquiring, capturing, creating, and storing. Knowledge acquiring materializes from external parties through training, inviting experts, or perhaps recruitment, the pathways through which knowledge enters the organization from external sources.
Staffs at various levels are also encouraged to continually study at tertiary level, as well as to attend courses or internship at domestic and foreign institutions. Acquisition of knowledge in DGT is also carried out through research, either by the DGT's staffs themselves or by other parties. The results of other parties' researches, which are conducted in the DGT, are required to be submitted to DGT, usually stored in a repository or library. DGT also conducts internal researches, mostly in the forms of monitoring and evaluating and also by working with other parties.

As we will see, knowledge creation also occurs in other subprocesses of distribution and utilization. In the process of knowledge transfer, there are at least two parties involved, each as a source and a recipient. On the receiving end, by utilizing absorbing capacity, knowledge is acquired. Similarly for knowledge utilization, often new knowledge is created in the subprocess. For example, knowledge in skills develops when it is applied, or at least, tried to be practiced during training. Similarly, for knowledge related to corporate values and integrity norms, learning process occurs during any cases of imposition of sanctions for violations. Such cases serve as learning resources for the offenders themselves as well as for other employees. In essence, the parties actively explore the lessons-learned or at least passively through the deterrent effects. Those cases show that in every process and administrative activity, new knowledge might be created.

Another aspect of acquisition is 
storing which directly deflects attention to technology supports. Therefore, most of these cases will be discussed in the technology section. However, beyond technology, DGT has long had libraries that traditionally serve as the warehouse of explicit knowledge. Additionally, as many public organizations do, DGT also maintains archives and document management system.

The distribution of knowledge, which is the main phase of KM process, is massively carried on through education and training. As part of the ministry of finance, most of DGT's education and training is conducted by the financial education and training agency (FETA). The agency organizes a range of program ranging from pre-service training to knowledge development and skills training (in-service training), concerning both taxation materials and those related to certain job requirements. In various occasions, tailor-made training is also held. Now FETA has become a corporate university following the institutional transformation program of the ministry of finance.

$N$ evertheless, FETA has limited (quantity and quality) capacity to respond to the needs of a modern tax administration. Therefore, DGT also seeks to manage its personnel capacity development. DGT even puts this issue as part of competency management, including to improve professionalism, productivity, and integrity. Each employee is targeted to reach certain training hours and the participation in training is also counted as one of the performance indicators.
Professional development is carried out through various training and development programs. Beyond the core activities, other activities have also comprised knowledge sharing tradition, such as in-house training (IHT) and technical guidance. IHT is knowledge sharing sessions between employees, usually from employees who have previously been trained, and often conducted informally and face-to-face. Formal meetings, such as operational, coordination, and national leader meetings, are also means of transferring knowledge.

In the latest developments, after the Kompatriot established, it began to emerge and grow various forms of the community of practice (COP), such as tax talks, book reviews, and others. In fact, a variety of the already-running forums can also be considered as COP or community of interest (COI), such as the forum of service section, collection division, or other segmented functions, where participants gather to hold a conference nationally or regionally. Another variation is the online discussion forums on the internal portal which can be referred to as virtual COP and WhatsApp groups (WA) which often become a kind of mobile COP.

From the entire sequence of process cycles, perhaps it is the utilization part that is still marginalized. If we have to find one good example of KM initiatives which has clear benefits, then it is the utilization of tax knowledge base (TKB) by employees and call center agents (at the office of tax information service/KLIP). In the TKB, in addition to 
the codification of regulations, there are also available a summary of content, frequently asked question (FAQ), and other important information. By utilizing the facility, the call center agent can quickly answer the caller's inquiry. Another form of relatively good utilization is Antariksa, a portal and repository for tax auditing knowledge, which maintains and provides various modules and training records. The assigned auditors may access the case modules from the previous audit available in the system. The application is also used for trainers mapping in specific subjects, which supports the decentralized training planning.

Table 2 Maturity Level of KM in DGT: Process

Source: Pee \& Kankanhalli (2009) and Researcher's Analysis

\begin{tabular}{|c|c|c|}
\hline Level & G-KMMM's Assessment Instruments for Process & Main Reponses \\
\hline $\begin{array}{c}1 \\
\text { Initial }\end{array}$ & No KMinitiatives & \\
\hline \begin{tabular}{c|c}
2 \\
Aware
\end{tabular} & 1 Is the knowledge that is indispensable for performing routine task documented? & Yes, partially. \\
\hline \begin{tabular}{c|}
3 \\
Define
\end{tabular} & $\begin{array}{l}2 \text { Does the KMS improve the quality and efficiency of work? } \\
3 \text { Is the process for collecting and sharing information formalized? } \\
\text { - Best practices and lessons learnt are documented }\end{array}$ & $\begin{array}{l}\text { Not sure. } \\
\text { No. }\end{array}$ \\
\hline \begin{tabular}{c|c}
4 \\
Managed
\end{tabular} & $\begin{array}{l}4 \text { Are the existing KM systems actively and effectively utilized? } \\
5 \text { Are the knowledge processes measured quantitatively? }\end{array}$ & $\begin{array}{l}\text { Yes, partially. } \\
\text { Yes, for particular. }\end{array}$ \\
\hline \begin{tabular}{c|c} 
\\
Optimisng
\end{tabular} & 6 Can the existing KMprocesses be easily adapted to meet new business requirements? & No. \\
\hline
\end{tabular}

Unfortunately, the G-KMMM framework provides a few instruments for measuring process maturity. The DGT has relatively acceptable KM processes, but they can not be captured comprehensively by only six questions made by Pee \& Kankanhalli (2009). Therefore, apart from many achievements above, for the process element, KM at DGT is still at level 2 (aware). Moreover, it is still conditional, as it seems not yet fully meet all the requirements. For example, concerning the documentation, or the codification, of knowledge which is considered essential for the performance of routine tasks has not become a tradition. There is also no standard and formal process for the capturing and sharing of knowledge.
In administration, the concept of process is not just about what actually happened, but also the existence of formal tasks that actors should perform. Utilization of knowledge, on the other hand, is also still minimal and partial, fairly far from the comprehensive level of adaptation to address the challenges of the organization as a whole.

\section{D.2.3. Technology}

Like most other development of information systems in DGT, technology for KM is also made partial, in-house, and not departing from a grand design. As already mentioned, there are at least 21 applications or portals that can be claimed as running the role of 
knowledge management systems (KMS). However, not all of these portals are dedicated to KM, except for some, such as Antariksa, TKB, and Wikitax (a Confluence-based portal). Beyond that, there could still be other applications or portals that have not been deployed or may still be in the development process.

The above - mentioned technology is primarily for storing explicit knowledge or what McNabb (2007) puts it as a knowledge registry. Ideally, the registry should also serve as a knowledge locator, identifying where in the organization to find expertise or experts providing knowledge. DGT information systems, in fact, do not yet have expert locator features or rubrics that bring together knowledge seekers and knowledge bearers. There are indeed discussion forums on the internal portal, but they are not dedicated to
KM purpose. The forums cannot be relied upon as a place to search for experts or the knowledge directly.

In short, the existing capacity of information systems is only able to meet sectoral and narrow needs. The technology systems and infrastructure are not sufficient to entirely cover the large archipelagic territory, for all 42,000 employees, and for all the varied clusters of knowledge. In fact, it is the IT system that is supposed to be able to facilitate the giant organization with so many employees, most of whom do not know and difficult to interact with each other. Actually, DGT has a SharePoint-based internet portal, but it is still in the old version. The development of the integrative $\mathrm{KM}$ portal has become an agenda, but until the day of this research, it has not come true yet.

Table 3 Maturity Level of KM in DGT: Technology

Source: Pee \& Kankanhalli (2009) and Researcher's Analysis

\begin{tabular}{|c|c|c|}
\hline Level & G-KMMM's Assessment Instruments for Technology & Main Reponses \\
\hline \begin{tabular}{c|}
1 \\
Initial
\end{tabular} & No KM initiatives & \\
\hline \begin{tabular}{c|c}
2 \\
Aware
\end{tabular} & $\begin{array}{l}1 \text { Are there pilot projects that support KM? } \\
2 \text { Is there any technology and infrastructure in place that supports KM? } \\
\text {-E.g. Intranet portal } \\
\text {-E.g. Environments supporting virtual teamwork }\end{array}$ & $\begin{array}{l}\text { Yes. } \\
\text { Yes. }\end{array}$ \\
\hline \begin{tabular}{c|c}
3 \\
Define
\end{tabular} & 3 Does the system support the business unit? & Yes. \\
\hline \begin{tabular}{c|c}
4 \\
Managed
\end{tabular} & $\begin{array}{l}4 \text { Does the KMS support the entire organization? } \\
5 \text { Is the KMS tightly integrated with the business processes? }\end{array}$ & $\begin{array}{l}\text { No. } \\
\text { No. }\end{array}$ \\
\hline \begin{tabular}{c|c}
5 \\
Optining
\end{tabular} & 6 Are the existing systems continually improved upon (e.g. continual investments)? & Yes. \\
\hline
\end{tabular}

By using the G-KMMM instrument to assess the technology sub-element, DGT's KM maturity seems to be at the higher range of level 3 (define).
This happens because there is already the piloting for the KM project (although sectoral) and there is a portal intranet that allows employees to work virtually. 
Another reason why level 3 is met because the system is able to support certain business units. DGT has should be able to reach level 4 if the KM technology can support the entire organization. Unfortunately, the KM technology system has not been tightly integrated with the entire business process.

Overall, using G-KMMM by Pee \& Kankanhalli (2009), KM in DGT can be expected to be at maturity level 2, but it is on its way to fulfill the level 3 characteristics. It must be kept in mind that the result is for the overall maturity of the organization as a whole. If units are diagnosed individually (G-KMMM itself can be applied for an organization as a whole and individual organizational units), then the maturity level may be higher in certain clusters or subprocesses, such as audit function and simply in the service cluster where codified knowledge (such as TKB) could be utilized more effectively.

Table 4 Overall Maturity Level of KM in DGT

Source: Pee \& Kankanhalli (2009) and Researcher's Analysis

\begin{tabular}{|l|c|c|}
\hline \multirow{2}{*}{ KM Elements } & \multicolumn{2}{|c|}{ Maturity Level } \\
\cline { 2 - 3 } & Each & Overall \\
\hline People & 2 & \\
Process: & & \\
- Acquisition & 2 & \\
- Distribution & 3 & 2 \\
- Utilization & 2 & \\
Technology & 3 & \\
\hline
\end{tabular}

Nevertheless, it needs to be recognized that there are weaknesses of G-KMMM, particularly in treating all elements and each unit equally. It should also be remembered that the KM analysis is highly dependent on the levels of aggregation, whether it is the unit, department, or the organization as a whole. In addition, the level determination in the G-KMMM scheme is also too rigid, all elements must be met, and the measurement is using the smallest value (round downward). If there is one aspect skipped (negative), then the overall level will go down. However, G-KMMM can, fortunately, serve as both an effective diagnostic tool for assessing KM efforts and a coherent roadmap that guides academic and practical KM endeavors. Thus, the platform can also be used to project the most ideal KM model for tax administration as will be discussed in the following section.

\section{D.3. Developing a KM Model for Tax Administration (FUTURE)}

As a complex organization, tax administration has complex business processes as well. Knowledge spreads throughout the business process, 
whether in core businesses, such as taxpayer registration, return processing and payment, supervision and audit, dispute resolution, collection, and criminal investigation, or in supporting processes.
To make it simple, the tax administration business process can be grouped into four major clusters, namely service delivery, compliance assurance, law enforcement, and supporting functions.

\section{Picture 1 Tax Administration Business Process Groups \\ Source: Researcher's Analysis}

\begin{tabular}{|l|c|c|}
\begin{tabular}{|c|c|}
\hline Service: \\
$\begin{array}{c}\text { Registration } \\
\text { Tax return } \\
\text { Payment } \\
\text { Information } \\
\text { Assistance }\end{array}$
\end{tabular} & $\begin{array}{c}\text { Compliance: } \\
\text { Supervision } \\
\text { Audit } \\
\text { 3rd party data } \\
\text { Data analytic }\end{array}$ & $\begin{array}{c}\text { Law enforcement: } \\
\text { Assessment } \\
\text { Criminal investigation } \\
\text { Collection } \\
\text { Dispute resolution }\end{array}$ \\
\hline HRM, Finance, IT, Asset management, legal, KM, PR, secretariat, etc. \\
\hline
\end{tabular}

Each cluster includes several processes. In the service cluster, some processes are intended to serve taxpayers, such as registration, tax return, payment, information, and assistance process. Although all processes are conducted under rules or even explicitly regulated in legislation, the force of coercion is not too obvious. Instead, the taxpayers are even treated like customers who deserve to get excellent services. The opposite extreme position is the law enforcement cluster, in which tax officers are taking actions coercively, especially in tackling tax evasion and fraud. In the middle, there is a supervisory cluster that combines law enforcement and service activities. Although the substance is the implementation of law provisions, the approach is more persuasive with the intention of growing cooperative compliance among taxpayers. The last is the cluster of supporting functions that embraces all corporate functions, outside the core business of tax administration.

\section{D.3.1. Types of Knowledge in Process Clusters}

Analyses on the data and information gathered from source documents and interviews suggest that DGT has a rich knowledge scope with a wide and varied taxonomy. The finding is supposed to simply represents the administrative tax condition in general. Of the four types of knowledge, process/procedure, content, case, and context (Gronau et al., 2016; Nonaka \& Takeuchi 1995; Sejdija 2012), all of them 
The combination of the types of knowledge perspectives and the clusters of tax administration business process results in comprehensive research findings, which can be summarized as follows.

Table 5 Types of Knowledge in Process Clusters

Source: Researcher's Analysis

\begin{tabular}{|l|c|c|c|c|}
\hline \multicolumn{1}{|r|}{ Types of $\mathrm{K}$} & PROCEDURE & CONTENT & CASE & CONTEXT \\
\hline Process Clusters & $* * * *$ & $* * *$ & $*$ & $*$ \\
\hline Comice & $* * *$ & $* * *$ & $* * *$ & $* * *$ \\
\hline Law Enforcement & $* *$ & $* * *$ & $* * * *$ & $* * * *$ \\
\hline Supporting Functions & $* *$ & $* *$ & $* * *$ & $* * * *$ \\
\hline
\end{tabular}

In the service cluster, the most widely flowing knowledge is procedural knowledge. "PROCEDURE" deals with processes and procedures in routine tasks, such as service procedures, return submissions, and payments. Most of the knowledge is in the form of regulations, rules, ordinances, and manuals. Some of the knowledge also meets the characteristics of "CONTENT," which in essence consists of fact and rules (Sejdija, 2012). On the other hand, "CASE" and "CONTEXT" are relatively rarer in the service cluster, perhaps because of the availability of standard operating procedures (reinforced by information systems) which applies uniformly.

Jump to the next row of the law enforcement cluster, there is a lot of unique and valuable knowledge in the form of CASE and CONTEXT which is followed by CONTENT and a little PROCEDURE. Activities in the cluster are typically related to managing various cases. Knowledge created in these cases is highly varied, distinctive, and attached to the personal head. Interestingly, on many occasions, the cases were cross-division, recurring, and most likely appearing in other units as well. For example, the knowledge relates to a tax dispute case, which usually stems from an audit correction that is not approved by taxpayer, who then filed an objection and appeal attempt. At the same time, the supplementary taxes from audit findings and corrections may appear to be arrears that must be collected coercively.

Interestingly, in the compliance cluster, the distribution of knowledge is relative more evenly according to the type of PROCEDURE, CONTENT, CASE, and CONTEXT. Most of the processes in this cluster contain activities that are intended to test taxpayer compliance such as the correctness of tax calculating or the timeliness of tax reporting. Knowledge is created by a wide range of activities: supervisory, monitoring, business intelligence 
(understanding the business structure and taxpayer behavior), or various variations of data analytics.

In the cluster of supporting functions, there are a lot of activities related to the management of internal resources, such as assets, finance, personnel, and also information technology. Knowledge in this cluster is almost the same as knowledge in other organizations, which principally can be classified as CONTEXT. Tax administration is an open organization and always interacts directly with the environment from which tax administration gets resources (input) and where it gives output. Various knowledge is scattered here, such as interpersonal skill, negotiation skill, art, etc, which are derived from interaction with the environment or the outside world. As with most organizations, these supporting functions of tax administration also possess knowledge about themselves as an organization.

\section{D.3.1. Testing the Knowledge Validity}

For each type of knowledge identified in the tax administration, it is necessary to further test its validity whether it meets the components of the definition of knowledge. The definition used here is the one that is proposed by Davenport \& Prusak (1998), i.e. is "a fluid mix of framed experience, values, contextual information, and expert insights that provides a framework for evaluating and incorporating new experiences and information." From the definition, four important components can be procured, namely professional insights, experience, values, and context. Another dimension to be considered is the shapes of knowledge as tacit or explicit (Nonaka \& Takeuchi, 1995). This part will discuss each of the four types of knowledge found in the tax administration deeper to measure up the fulfillment of the knowledge definition's components.

Table 6 Knowledge Validity

Source: Researcher's Analysis

\begin{tabular}{|l|c|c|c|c|}
\hline \multicolumn{1}{|c|}{ TYpes of $\mathrm{K}$} & PROCEDURE & CONTENT & CASE & CONTEXT \\
\hline Professional insight & $* * * *$ & $* * * * *$ & $* *$ & $*$ \\
\hline Experience & $*$ & $*$ & $* * * * *$ & $* * * * *$ \\
\hline Value & $* * *$ & $*$ & $* *$ & $* * * * *$ \\
\hline Context & $*$ & $* *$ & $* * * * *$ & $* * * * *$ \\
\hline KShape & $* * * * *$ & $* * * *$ & $* *$ & $* *$ \\
\hline Explicit & $* *$ & $* *$ & $* * * * *$ & $* * * * *$ \\
\hline Tacit
\end{tabular}


Firstly, for the PROCEDURE and CONTENT types that mainly are explicit. The PROCEDURE type meets the definition of knowledge, thanks essentially to the component of professional insight. PROCEDURE does contain easily documented routine knowledge, stored policies, guidelines, and standard operating procedures, all knowledge about routine tasks. Similarly, CONTENT also consists of the knowledge of facts and rules (Sejdija 2012) which in practice contains a lot of regulation or information generated from data processing. In tax administration, CONTENT is not only tax-related knowledge in the core business cluster (service, compliance, law enforcement), but also the non-tax knowledge found in supporting functions, such as staffing, finance, asset management, and other affairs. The components that validated both PROCEDURE and CONTENT as knowledge predominantly come from professional insight, although there is also (but not much) the contribution of experience, value, and context. In addition, by using the term of Nonaka and Takeuchi (1995), they meet explicit knowledge criteria that can be expressed in terms of hard data, scientific formulas, codified procedures, or universal principles.

Meanwhile, the CASE type is basically in the form of experience, values, and context. This type of knowledge is the richest and most important and is usually unique to tax administration. It has a significant role for the collective memory of an organization, as it might be the basis for the development of knowledge of the employees, the entire organization, and even as a basis for the legislative impact assessment.

As for CONTEXT, most of the knowledge contains experiences collected from individual interactions with the environment and the general world. Similar to the CASE, CONTEXT is also very rich consists of various knowledge, skills, and even values. Apart from having gained from a specific situation and interaction, the CONTEXT knowledge can also be a skill learned from trials and errors at practical actions. The accumulation of experiences gathered from the field shapes the skill as well as the attitude (behavior) of employees. It is also shaped by values and norms that surround individual and organizational operations. Perhaps that is why they are called as encultured knowledge or embodied knowledge (Gronau et al., 2016). At many times, CONTEXT is special, happens once, and cannot be repeated, what are so-called event knowledge. Therefore, CONTEXT meets the definition of knowledge also by considering situational factors, or aspects of the surrounding environment (the context).

From the perspective of knowledge shape, both CASE and CONTEXT are most likely to meet the definition of tacit knowledge. This refers to human roles in creating, storing, and distributing knowledge, especially relates to the contextual situation. It must be kept in mind that the context component can only be given by humans, the only actor that can convert data and information to meet the criteria of knowledge (Davenport and Prusak 1998). 


\section{D.3.3. The KM Model for Tax Administration}

The temporary conclusion that can be drawn is that the types of knowledge PROCEDURE and CONTEXT come largely from professional insight. While the types of CASE and CONTEXT mostly come from experience, value, and contextual interaction. Knowledge in tax administration has a distinctive feature according to its process cluster. The PROCEDURE type is primarily found in the service process group and the CONTEXT type is mostly found in the law enforcement cluster and supporting functions. For the CONTENT type, knowledge is distributed abundantly in the service cluster, compliance, and law enforcement. While the CASE type is dominant in compliance and law enforcement clusters. Viewed from the shape of knowledge, PROCEDURE and CONTENT in tax administration are normally in explicit form, while CASE and CONTEXT are largely tacit.

The findings are very useful as a foundation for the development of KM model for tax administration. Below is the KM Model for an ideal tax administration.

\section{Picture 2 The KM Model for Tax Administration Source: Researcher's Analysis}

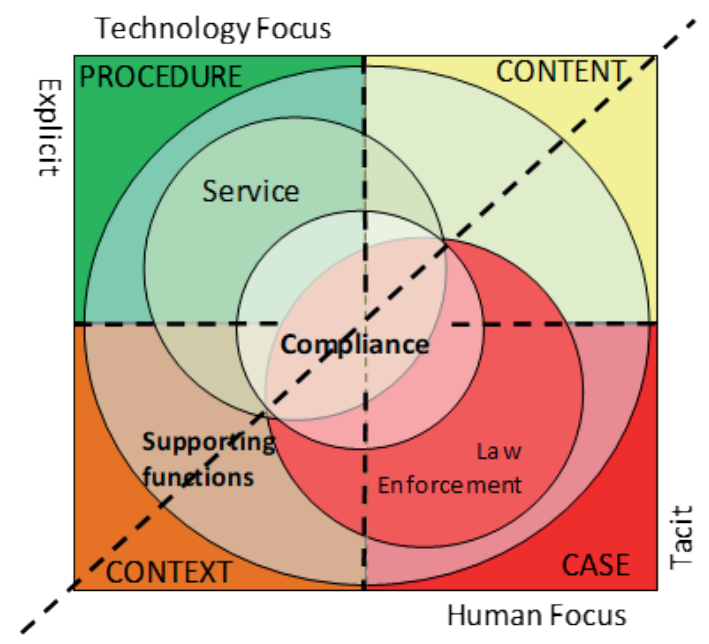

The clusters of the process are represented by circles which symbolically display the relative position of each cluster in the context of four types of knowledge, which are represented by the four quadrants. Each circle is partly overlapping, not mutually exclusive, demonstrating the potential for interacting and mutual exchange of knowledge between clusters. However, the circulation of each type of knowledge in its respective circles is much more intensive, fueled by the similarity of needs of the knowledge seekers and the supply of knowledge by knowledge-holders.

It is shown in the Picture 2 that the process clusters and thus the distribution of 
Firstly, for the PROCEDURE and

CONTENT types that mainly are explicit. The PROCEDURE type meets the definition of knowledge, thanks essentially to the component of professional insight. PROCEDURE does contain easily documented routine knowledge, stored policies, guidelines, and standard operating procedures, all knowledge about routine tasks. Similarly, CONTENT also consists of the knowledge of facts and rules (Sejdija 2012) which in practice contains a lot of regulation or information generated from data processing. In tax administration, CONTENT is not only tax-related knowledge in the core business cluster (service, compliance, law enforcement), but also the non-tax knowledge found in supporting functions, such as staffing, finance, asset management, and other affairs. The components that validated both PROCEDURE and CONTENT as knowledge predominantly come from professional insight, although there is also (but not much) the contribution of experience, value, and context. In addition, by using the term of Nonaka and Takeuchi (1995), they meet explicit knowledge criteria that can be expressed in terms of hard data, scientific formulas, codified procedures, or universal principles.

Meanwhile, the CASE type is basically in the form of experience, values, and context. This type of knowledge is the richest and most important and is usually unique to tax administration. It has a significant role for the collective memory of an organization, as it might be the basis for 
knowledge are divided by a diagonal line. This division is not a rigid dichotomy between tacit and explicit knowledge, which is consistent with Nonaka \& Takeuchi's (1995) argument that both shapes of knowledge are not mutually exclusive but as complementary entities. Implicitly, this division attempts to convey a message about the KM strategy that should be pursued as well as the clue for the development of KM technology (technology solution or people solution).

How to apply the Model? Let's take the CONTEXT type of knowledge as an example. As mentioned, CONTEXT meets the definition of knowledge due to experience, value, and context components. In the area of supporting functions, CONTEXT can be knowledge related to integrity, which is a value related to behavior and attitude. The way of acquiring and distributing is through the internalization of corporate values and training intended to change the behavior and culture that must be intensive. At the utilization level, when knowledge is implemented through law enforcement of an offense, the offender or other parties would then know and learn (deterrent effects). All this tends to human focus.

\section{D.4. Discussion and Lessons Learned}

There are some important lessons to be learned especially regarding IT systems, KM strategies, and ideas for overcoming obstacles.

\section{D.4.1. Smart Strategy}

Findings in the KM Model above suggest that the KM strategy should be balanced between codification and personalization. Despite of any strategy and model of KM that will be applied in a tax administration, managers should pay attention to the following points. Firstly, the technology system is not everything but something. As commonly understood, technology is excellent for explicit and more accommodative for codified knowledge. That opens up the possibility of achieving scale in knowledge re-use. However, in addition to explicit knowledge and codification strategies, the IT system should also become a hub for personalization strategies. In other words, the KM system is also supposed to be accommodative to knowledge sharing for the CASE and CONTEXT types of knowledge that are embedded in the human heads and usually transferred from human to human.

An integrated and unified information platform is also useful for addressing organizational silos. Justifying the words of McNabb (2007) that "KM is more than technology, it is a social system," the IT system should be able to unite people who have diverse backgrounds and interests. It means that, in addition to the repository and the expert locator features, the IT system must also manifest as an integrated web-based portal that bridges collaboration among people. A good IT system can even generate mutual trust, willingness to share knowledge, and even top management support. Therefore, 
it is very important to make technology features as attractive as possible to be sophisticated and catchy to attract users' attention. For example, IT development should consider including visual analytics in measuring $\mathrm{KM}$ activity as performance indicators (Sultanow et al., 2017).

Second, the need to conduct knowledge audit \& mapping. Many benefits can be gleaned from knowledge auditings, such as identifying a gap between knowledge holders and seekers, and the need for KM measures. In addition to the commonly used knowledge grouping approach (tacit-explicit, individual-collective, formal-informal), in the context of tax knowledge, it also importantly needs to be divided between knowledge that is secret in nature (confidential) and the unclassified (open), and also between general and particular. Secret knowledge cannot be easily transacted, whereas the particular knowledge may not be easy to distribute as it may be less useful for others.

Third, strategy in harnessing or utilizing of knowledge. Knowledge is not an end in itself and, therefore, the KM campaign must be able to prove that KM is able to bring real benefits. Many KM initiatives died out because they failed to grab the attention of stakeholders, especially top management support. Knowledge management will not succeed in an organization unless it is backed by people with enough power and access to sufficient resources to make it work (Edwards, Collier, \& Shaw, 2005). In the midst of the abundance of more sexy issues that can be sold,
KM should be able to find something of a more real added values, for example, knowledge utilization that provides added value to process and performance. KM should promote its contribution to efficiency, productivity, and effectiveness, or other aspects of performance. Unfortunately, KM cannot directly affect the performance, but through various factors and variables which, if there were a correlation, is also difficult to measure. Therefore, the challenge is how to find a more pragmatic feature of KM which the benefits can be easily recognized.

In tax administration, a good example is KM related to the CASEs of tax disputes. A KM system acting as a repository of data, information, and knowledge about tax dispute cases can be used across functions of audit, dispute resolution, and collection. Thus, KM can prove itself as a collaborative tool that bridges the audit function that used to seem separated from the dispute resolution function. By connecting the disconnects, KM may contribute to high-quality audit and also lower the possibility of tax disputes and arrears. With KM support, the application of knowledge can be more optimal, especially in audit (correction), as well as the settlement of disputes and collection of tax arrears. Auditors can use knowledge as the basis for professional judgment and at the same time able to predict the "fate" of corrections and tax assessments if it eventually becomes tax arrears and tax disputes. Here KM also shows itself as capable of reducing the time and cost of solving problems, as well as improving the quality of solutions. 
In a more pragmatic environment, consideration should be given to the selection of harnessing features of knowledge that should be more real and close to revenue. For quick wins, some knowledge clusters can be prioritized, i.e. those that bring in fast money or discover tax evasion easily. In potential "excavation," for example, cases of previous tax findings can be used as a reference to a success story. KM can also prioritize areas that bring rewards more real and have a relationship with $\mathrm{KPI}$. Some features of innovation in service provisions, such as e-filing and e-payment, and e-invoice could also be claimed as a result of KM. Another option of quick win is by directing $\mathrm{KM}$ to strengthen MoF's corporate values, integrity, professionalism, synergy, service, and excellence.

\section{D.4.2. Solving Problems}

Mature $\mathrm{KM}$ is unlikely to be achieved in one giant leap (Pee \& Kankanhalli, 2009). Instead, it must go through gradual and holistic development. One of the important lessons to be learned is the need to overcome various obstacles. The good news is that constraints are usually twins born with the solution. First, to overcome the low interest of users and contributors, tax administration can rely on policy and regulation. Luckily for tax administration that gets used to the coercive power of tax law, a similar approach can be implemented in KM. In this context, DGT can also exploit the fact that Indonesia is a legal state (rechstaat), to issue a binding regulation that can be issued to support KM. This idea is in line with the coercive approach to form and introduce a new culture. Various studies conclude that mandatory participation is important to overcome reluctance to change and participate in the early phases. Coercion is a push factor as a complementary to pull factors such as a reward strategy. On the other hand, a reward strategy can be seen as a way of recognizing active employees and contributors. Establishment of a reward strategy for stimulating willingness to share knowledge combined with a clear definition of rules and supported by a friendly and satisfying knowledge exchanging system is believed to be significant underlying factors for KM success.

Second, to address the problems of people, there must be a dedicated unit that is recognized and clearly illustrated in the formal organizational structure. Some tax administration has a KM division, or even chief knowledge officer (CKO), indicating the seriousness of the tax administration in implementing KM from the organizational and process perspectives. To support optimal operation, the KM organization should be equipped with certified knowledge managers, supported by KM specialists and practitioners.

Third, it needs a massive campaign. KM movement needs to build a KM vision that aligns with the vision of the organization. For example, the campaign should urge the challenge the era of knowledge brings and needs to be anticipated, why it is important to be 
a knowledge worker and learning organization. Kompatriot is an example of a good concept. Considering knowledge as a strategic asset, Kompatriot tries to be the general orchestration of policy, people, process, and technology to enable DGT to deliver knowledge as a strategic asset. As suggested by Davenport and Prusak (1998), KM should function as a marketplace where knowledge can be traded and transacted efficiently between buyers, sellers, and brokers.

\section{D.4.3. Further Research}

This research is still a preliminary study conducted in the Indonesian national tax administration. Given the possibility of differences, further research can investigate this theme in more detail, by looking at tax administration in other countries or tax authorities at other levels of government (local, regional, or state). Also, given the weaknesses contained in G-KMMM, subsequent research may be able to use other maturity measurement tools. Similarly, taking into account the different scopes of work and institutional arrangements, the KM Model proposed by this study may be re-examined for improvement.

The second suggestion is to consider two knowledge contexts around taxation, namely as internal strategic assets and knowledge as commodities (marketable externally).
While the gap between knowledge holders and seekers is still unknown, it needs to be further examined whether the tax administration should externally provide knowledge to the public, taxpayers, at the level above just (tax) information. It has something to do with the function of information services and the assistance and the demands for tax administration to provide excellent service to the taxpayer. If so, should KM be sufficiently supported by official tax policies?.

This is important to be answered as knowledge is the power and tax administration is aware that, as an organization, it needs to develop strategies to achieve its mission. On the one hand, tax administration is required to maintain the confidentiality of taxpayers' data and information, while on the other hand, tax administration should be careful with the possibility of fraud related to tax knowledge. That is, the culture of confidentiality in the tax administration should be considered as well. Let alone the CONTENT, CASE or CONTEXT types of knowledge, even for the PROCEDURE knowledge that must be escorted carefully. The question is whether taxpayer education, which in fact is tax knowledge transfer, should be set free? If it is treated as a paid service, does it meet corruption definition? Finally, the inquiry would end up with a fundamental question: to what extent the tax administration should provide knowledge for the taxpayer?. 


\section{E. CONCLUSION}

There are several points of findings that make discussions about KM in tax administration are very interesting. KM offers many potential benefits to be gained related to performance, tax compliance, and integrity of the tax administration system. This could be increasingly interesting by considering that tax knowledge has a market and the potential for dark power in exploiting knowledge.

The study shows that the ongoing KM at DGT is still very infant. Using the G-KMMM scheme presented by Pee \& Kankanhalli (2009), the overall maturity level is at level 2 (aware). This is a performance record after about 10 years since the first $\mathrm{KM}$ initiative was announced.

Secondly, considering the uniqueness of the tax administration, this paper offers a general KM Model for tax administration. It serves as answering requests from previous researchers, such as Sultanow et al. (2017) that suggest developing a customized knowledge management system which suits unique bureaucratic hierarchies and cultural features. The KM Model is obtained by dividing the tax administration business process into 4 clusters of service, compliance, law enforcement, and supporting functions, as well as identifying the types of knowledge in tax administration by referring to a typology proposed by Lenk \& Wengelowski (2002) and Sejdija (2012). Its validity is then tested with the definition of knowledge according to Davenport \& Prusak (1998).
Thus, the resulting KM Model is a combination of the tax administration business process, types of knowledge, and components of the fulfillment of knowledge definition. By looking at the shapes of knowledge (tacit and explicit), the Model comes up with a more appropriate KM strategy proposal between codification and personalized strategy. To support it, KM needs a dedicated unit with competent personnel and resource support (especially IT) that are adequate for operational implementation and KM campaigns. Concerning the IT system, the technology should, in addition to the repository role, also act as a hub for inter-human interaction (tax knowledge market).

\section{F. BIBLIOGRAPHY}

[1] Alavi, M., \& Denford, J. (2001). Knowledge Management: Process, Practice, and Web 2.0. In M. Easterby-Smith, \& M. Lyles, Handbook of Organisational Learning and Knowledge Management (pp. 1-20). Chichester: Wiley.

[2] Alavi, M., \& Leidner, D. (2001). Review: Knowledge Management and Knowledge Management Systems: conceptual foundations and research issues. MIS Quarterly, Vol. 25 No. 1, 107-136.

[3] Alink, M., \& van Kommer, V. (2011). Handbook for Tax Administration. Amsterdam: IBFD.

Boyne, G. (2002). Public and private management: What's the difference? Journal of Management Studies, 39, 97-122.

[4] Castaneda, D. I., Manrique, L. F., \& Cuellar, S. (2018). Is organizational learning being absorbed by knowledge management? A systematic review. Journal of Knowledge Management, Vol. 22 Issue: 2, 299-325. 
[5] Cong, X., Li-Hua, R., \& Stonehouse, G. (2007). Knowledge management in the Chinese public sector: empirical investigation. Journal of Technology Management in China, 2 Iss 3, 250-263.

Dalkir, K. (2011). Knowledge Management in Theory and Pactice (Second edition). Cambridge: The MIT Press.

[6] Davenport, T. H., \& Prusak, L. (1998). Working Knowledge: How Organizations Manage What They Know. Boston: Harvard Business School Press.

[7] Drucker, P. (1993). Post-Capitalist Society. Oxford: Butterworth Heinemann.

Edwards, J. S., Collier, P. M., \& Shaw, D. (2005). Knowledge Management and Its Impact on the Management Accountant. London: CIMA.

[8] Evans, C., \& Carlon, S. (2015). Tax knowledge in large corporations: Insights and analysis.

[9] Gronau, N., Ullrich, A., Thim, C., \& Vladova, G. (2016). A Proposal to Model Knowledge in Knowledge-Intensive Business Processes.

[10] Hansen, M., Nohria, N., \& and Tierney, T. (1999). What's your strategy for managing knowledge? Harvard Business Review, March-April,106-116.

[11] Hasseldine, J., Holland, K., \& Rijt, P. v. (2011, January). The Market for Corporate Tax Knowledge. Critical Perspectives on Accounting, 22(1), 39-52.

[12] Kianto, A., Vanhala, M., \& Heilmann, P. (2016). The Impact of Knowledge Management on Job Satisfaction. Journal of Knowledge Management, 20 Issue: 4, 621-636.

[13] Lin, H. (2014). A multi-stage analysis of antecedents and consequences of knowledge management evolution. Journal of Knowledge Management, Vol. 18 No. 1, 52-74.

[14] McNabb, D. E. (2007). Knowledge Management in the Public Sector A Blueprint for Innovation in Government. New York: M.E. Sharpe, Inc.

[15] McNabb, D. E. (2016). Research Methods for Political Science: Quantitative and Qualitative Approaches (2nd ed.). London; New York: Routledge; Taylor \& Francis Group.

[16] Nonaka, I., \& Takeuchi, H. (1995). The Knowledge Creating Company. New York: Oxford University Press.
OECD. (2006). Strengthening Tax Audit Capabilities: General Principles and Approaches. OECD.

OECD. (2010). Citizen-State Relations: Improving Governance through Tax Reform. OECD.

[17] Pee, L. G., \& Kankanhalli, A. (2009). A Model of Organizational Knowledge Management Maturity based on People, Process, and Technology. Journal of Information \& Knowledge Management, 8 (2), 1-21.

[18] Schlemenson, A. (1992). Organizational Structure and Human Resources. In R. Bird, \& M. Casanegra de Jantscher, Improving Tax Administration in Developing Countries. Washington: IMF .

[19] Sejdija, F. (2012). Knowledge Management in Public Administration: Critical Success Factors and Recommendations. Neuware: GRIN Verlag.

[20] Serenko, A. (2013). Meta-analysis of scientometric research of knowledge management: discovering the identity of the discipline. Journal of Knowledge

[21] Management, 17 No. 5, 773-812.

Sestakova, M. (2017). Problems of Knowledge Transfer in the Field of Taxation. International Workshop on Knowledge Management. Trenčín, Slovakia: IWKM.

[22] Soo, C., Devinney, T., Midgley, D., \& Deering, A. (2002). Knowledge Management: Philosophy, Processes, and Pitfalls. California Management Review, 44, No. 4, 129-15.

[23] Sultanow, E., Vladova, G., \& Ullrich, A. (2017). Visual Analytics Supporting Knowledge Management: A Case Study of Germany's. Conference Paper · December 2017.

[24] Willem, A., \& Buelens, M. (2007). Knowledge Sharing in Public Sector Organizations: The Effect of Organizational Characteristics on Interdepartmental Knowledge Sharing. Journal of Public Administration Research and Theory, Volume 17, Issue 4, 1 October 2007, 581-606.

[25] World Bank. (2009). A Handbook for Tax Simplifcation. Washington D.C: World Bank Group.

[26] Yin, R. K. (2014). Case Study Research: Design and Methods. Thousand Oaks, CA: SAGE Publications. 